\title{
KUALITAS INFORMASI AKUNTANSI : PERLUNYA PENGETAHUAN DAN KUALITAS SISTEM
}

\author{
Sri Dewi Anggadini ${ }^{1}$, Ari Bramasto ${ }^{2}$, Rafa Nafisah ${ }^{3}$ \\ 1,3Universitas Komputer Indonesia, sri.dewi@email.unikom.ac.id; rafanfsh25@gmail.com \\ ${ }^{2}$ Universitas Langlang Buana, arya_bravo@yahoo.com
}

\begin{abstract}
ABSTRAK
Laporan keuangan dikatakan berkualitas karena dipengaruhi oleh banyak faktor termasuk pengetahuan akuntansi dan kualitas sistem informasi akuntansi. Penelitian ini bertujuan untuk mengetahui seberapa besar pengetahuan akuntansi dan kualitas sistem informasi akuntansi menimbulkan dampak terhadap kualitas laporan keuangan di UMKM Alas Kaki Cimahi. Metode yang digunakan dalam penelitian ini adalah deskriptif kuantitatif. Teknik pengumpulan data yang digunakan adalah kuesioner (angket) yang dikirimkan kepada responden yaitu pemilik, manajer, dan bagian keuangan melalui pemilihan sampel jenuh yang artinya seluruh jumlah populasi dijadikan sampel. Metode analisis data yang digunakan untuk menggambarkan tanggapan responden dengan melihat persentase skor aktual terhadap skor ideal. Hasil dari penelitian ini menunjukan bahwa pengetahuan akuntansi pada UMKM Alas Kaki Cimahi dapat dikatakan cukup baik, namun masih terdapat kelemahan dalam indikator komunikasi. Kualitas sistem informasi akuntansi pada UMKM Alas Kaki Cimahi dapat dikatakan cukup baik, namun masih terdapat kelemahan dalam indikator efisien. Selanjutnya kualitas laporan keuangan pada UMKM Alas Kaki Cimahi dapat dikatakan cukup baik, namun masih terdapat kelemahan dalam masih terdapat kelemahan dalam indikator dapat dipahami. Dapat disimpulkan bahwa pengetahuan akuntansi dan kualitas sistem informasi akuntansi berdampak pada kualitas informasi akuntansi. Penelitian ini memiliki implikasi manajerial berupa peningkatan pengetahuan mengenai unsur-unsur yang mempengaruhi kualitas informasi akuntansi yang dapat dijadikan dasar dalam pengambilan keputusan.
\end{abstract}

Kata Kunci : Pengetahuan Akuntansi, Kualitas Sistem Informasi Akuntansi, Kualitas Laporan Keuangan

\begin{abstract}
Financial reports are said to be of good quality because they are influenced by many factors including accounting knowledge and the quality of accounting information systems. This study aims to determine how much accounting knowledge and the quality of accounting information systems have an impact on the quality of financial reports at UMKM Alas Kaki Cimahi. The method used in this research is descriptive quantitative. The data collection technique used is a questionnaire (questionnaire) sent to the respondents, namely owners, managers, and the finance department through the selection of saturated samples, which means that the entire population is sampled. The data analysis method used to describe respondents' responses by looking at the percentage of the actual score against the ideal score. The results of this study indicate that the accounting knowledge at UMKM Alas Kaki Cimahi can be said to be quite good, but there are still weaknesses in communication indicators. The quality of the accounting information system at UMKM Alas Kaki Cimahi can be said to be quite good, but there are still weaknesses in efficient indicators. Furthermore, the quality of the financial reports at UMKM Alas Kaki Cimahi can be said to be quite good, but there are still weaknesses in that there are still weaknesses in the indicators that can be understood. It can be concluded that accounting knowledge and the
\end{abstract}


quality of accounting information systems have an impact on the quality of accounting information. This research has managerial implications in the form of increasing knowledge about the elements that affect the quality of accounting information that can be used as a basis for decision making.

Keywords: Accounting Knowledge, Quality of Accounting Information Systems, Quality of Financial Reports

Naskah diterima : 30-06-2021, Naskah dipublikasikan : 30-11-2021

\section{PENDAHULUAN}

Mengacu kepada Undang-undang 20 Tahun 2008 berkenaan dengan Usaha Mikro, Kecil dan Menengah, usaha kecil merupakan aktivitas ekonomi produktif mandiri. Sektor Usaha Mikro, Kecil Menengah (UMKM) berperan penting untuk pemerintah sebagai pendorong perkembangan perekonomian Indonesia. Kualitas laporan keuangan UMKM memperlihatkan Pertumbuhan UMKM. Kelangsungan hidup usaha berikut pertumbuhan dari laporan keuangan dibuat dan dipelajari pemilik sehingga diketahui kesinambungan aktivitas bisnisnya (Hani et al., 2018). Hambatan laporan keuangan UMKM terlihat dari beberapa usaha mikro, kecil, dan menengah kesulitan memperoleh akses permodalan diakibatkan terbatasnya literasi keuangannya.. Penyusunan laporan keuangan umumnya membutuhkan pengetahuan berkenaan dengan akuntansi dasar beserta siklusnya. Perusahaan mustahil mengingat keseluruhan kejadian transaksi pada setiap aktivitas sebuah bisnis mengabaikan proses beserta sistem pencatatan periodik serta tersaji sistematis, tentu saja perlu pemahaman pengetahuan akuntansi yang diperuntukkan menyajikan sebuah informasi akuntansi didalam suatu bisnis (Hendro, 2011).

Sektor UMKM dan sektor Teknologi Informasi (TI) dapat mendorong perkembangan ekonomi, keduanya tak dapat dipisahkan perkembangannya. Selain komunikasi dapat menjadi lebih luas, keterjangkauan pasar, dan promosi dengan gencar UMKM, namun TI mampu pula menyokong aktivitas keuangan UMKM yang berkembang efektifitas dan efisiensi meningkat sesuai sistem akuntansi dengan TI sebagai basisnya. Teknologi Informasi yang tak terbendung perkembangannya, Namun UMKM di Indonesia belum mampu secara maksimal kesempatan teknologi tersebut dalam upaya menjadi berkembang. Chief Lembaga Riset Telematika Sharing Vision, Dimitri Mahayana, memaparkan hasil surveinya TI UKM 2017 Sharing Vision di akhir semester pertama tahun ini memperlihatkan, tidak banyak UKM menggunakan sistem akuntansi TIK sebagai basis pengerjaannya. Menurut Meiryani \& Susanto (2018), Kualitas sistem informasi akuntansi dipengaruhi oleh penggunaan Teknologi Informasi. Sistem Informasi Akuntansi karena kualitas informasi teknologi yang belum dimanfaatkan secara maksimal berfungsi dengan baik, infrastruktur teknologi informasi yang tersedia belum sepenuhnya dapat diandalkan, dan dukungan kelompok teknologi informasi belum sepenuhnya efektif. Sebagaimana yang diungkapkan Laudon dan Laudon (2014) Performa baik dari penerapan kualitas sistem informasi akuntansi mampu diperolehnya kualitas informasi akuntansi baik pula sehingga pengguna mempergunakannya dalam menetapkan keputusannya (Purnamasari, 2016).

Ada pun fenomena terkait laporan keuangan pada Charlie Queen Pet Shop Garut, bahwa pemilik mengatur keuangan memiliki dasar pengetahuan akuntansi yang masih minim dan hanya sekedar mempedulikan pendapatan yang melebihi modal awal tanpa memperhatikan laporan keuangan dalam pengambilan keputusan usaha. Selain itu, memiliki sumber pendapatan dari usaha dagang dan jasa yang sudah menggunakan komputer, namun belum menggunakan sistem yang terintegrasi. Cheung et al., (2010) Sebagian besar orang yang diwawancarai dan responden lain setuju bahwa perdebatan tentang kualitas informasi akuntansi dipicu oleh serangkaian kegagalan perusahaan. Mereka menyebut jatuhnya Enron, sebagian besar sebagai akibat dari 
transaksi off-balance sheet-nya, dan globalisasi pasar modal, sebagai faktor yang membawa debat kualitas menjadi perhatian publik. Pada penelitian oleh Baihaqi (2016), menunjukan bahwa Terdapat pengaruh Pengetahuan Akuntansi Pelaku Usaha terhadap Kualitas Laporan Keuangan UMKM sejalan dengan penelitian oleh Purwati (2014). Pada penelitian terdahulu oleh Agustin (2019) mengemukakan bahwa kualitas sistem informasi akuntansi berpengaruh terhadap kualitas laporan keuangan sejalan dengan penelitian oleh Rivaldi (2019) dalam penelitiannya menyimpulkan bahwa semakin banyak pengetahuan akuntansi yang dimiliki pengguna maka semakin berkualitas informasi akuntansi yang diolah. Adapun perbedaan penelitian ini dengan penelitian sebelumnya terdapat dari indikator-indikator yang membentuk variabel di penelitian ini dan hal ini dijadikan novelty pada penelitian ini.

\section{KAJIAN LITERATUR}

\section{Pengetahuan Akuntansi}

Bagi pelaku atau pemilik Usaha Mikro, Kecil, Menengah (UMKM) membutuhkan Pengetahuan Akuntansi pada penyusunan laporan keuangan. Akuntansi merupakan sistem informasi dengan tahapan Identifikasi, perekaman, dan melakukan komunikasi aktivitas ekonomi di organisasi pada penggunanya yang memiliki kepentingan (Weygandt, et al., 2018). Indikator dalam penelitiannya Pengetahuan Akuntansi memanfaatkan pengetahuan keutamaan dari proses pada akuntansi sebagai berikut:

\section{Identifikasi}

Pada tahap awal proses akuntansi, perusahaan melakukan identifikasi aktivitas ekonomi yang berhubungan bisnisnya. Aktivitas ekonomi tersebut yakni kejadian transaksi operasional pada perusahaan dengan bukti transaksi sebagai pendukungnya. Sejak awal proses identifikasi dilakukan pengumpulan bukti transaksi pada periode tertentu. Proses mengidentifikasi dilakukan melalui pengelompokkan diantara bukti-bukti transaksi sesuai jenis transaksinya supaya proses penjurnalan bisa dikerjakan.

\section{Pencatatan}

Proses dalam tahapan ini meliputi pencatatan dilanjutkan dengan klasifikasi dan penyesuaian transaksi-transaksi yang sebelumnya telah melalui proses identifikasi sesuai kronologis beserta sistematikanya tentu saja ke dalam format catatan perusahaan misalnya : jurnal, buku besar, neraca saldo, dan buku pembantu serta buku harian lainnya.

3. Komunikasi

Tahap proses ini keadaan keuangan di komunikasikan dengan perusahaan melalui laporan keuangan yang telah tersusun serta penyajiannnya diperuntukkan untuk para pengguna laporan keuangan agar bisa mendukung pengambilan keputusannya.

Chen \& Gong (2019) Manajer harus lebih berpengetahuan tentang perusahaan, industri dan sejenisnya, dan lingkungannya secara keseluruhan. Ini akan menempatkan manajer pada posisi yang lebih baik untuk mengevaluasi kinerja relatif perusahaan, dan memahami dan memprediksi peristiwa ekonomi, serta dampaknya terhadap perusahaan.

\section{Kualitas Sistem Informasi Akuntansi}

Pengertian kualitas yaitu standar atau tolak ukur yang telah ditetapkan (Walujo et al., (2018). Tujuan mendasar dari SIA adalah untuk mendokumentasikan peristiwa ekonomi dan menangkap pengaruhnya terhadap posisi keuangan organisasi. Sistem informasi akuntansi merupakan suatu sub sistem yang bersumber lewat Sistem Informasi Manajemen (SIM) berisi 
informasi akuntansi dan keuangan, berikut informasi lain juga sumber asalnya dari pengolahan rutin atas transaksi akuntansi agar informasi keuangan yang dihasilkannya berdasarkan basis data akuntansi sesudah pemrosesan baik yang diperuntukkan bagi managerial berkepentingan maupun eksternal (Muda, 2017). Kualitas Sistem Informasi Akuntansi sebagai berikut:

1. Fleksibel, sistem mampu dengan cepat beradaptasi berdasarkan pada perubahan lingkungan bisa juga disesuaikan dengan kebutuhan perusahaan.

2. Efektif, sistem mampu memperoleh keluaran yang dimanfaatkan pengguna informasi baik internal begitu pula eksternalnya dalam hal pengambilan keputusannya.

3. Efisien, sistem bisa memproses informasi secepatnya berikut ketepatan dengan cara pemborosan dan kerugian yang ada pada sumber daya diminimalisir.

Algrari \& Ahmed (2019) Perkembangan sistem informasi akuntansi memiliki pengaruh yang signifikan terhadap kinerja dan efektivitas operasi dalam organisasi, karena manajemen organisasi membutuhkan informasi yang bercirikan konsistensi dan kepercayaan dalam pengambilan keputusan.

\section{Kualitas Laporan Keuangan}

Bentuk usaha selayaknya dalam penyusunan laporan keuangan memiliki kualitas agar terpantau perkembangan dan kesehatan perusahaannya. Zamzami dan Nusa (2016) memaparkan bahwa laporan keuangan merupakan sekumpulan berdasarkan beberapa informasi keuangan yang dipergunakan oleh keterlibatan beberapa pihak dalam mendukung proses pengambilan keputusannya ( Zamzami \& Nusa, 2016). Kualitas Laporan Keuangan memiliki Indikator sesuai pernyataan Zamzami dan Nusa (2016) yakni sebagai berikut:

\section{Dapat dipahami}

Penyajian dan penyusunan di setiap laporan keuangan selayaknya ditata sesuai sistematis supaya bisa dipahami. Pemahaman karakter diimbangi para penggunanya memadai pula pengetahuannya. Sehingga laporan keuangan yang tersusun memiliki kesesuaian menurut batas para pengguna dalam memahaminya.

2. Relevan

Penyusunan Laporan keuangan seharusnya relevan bagi pengguna pada saat pengambilan keputusannya, hal ini menyebabkan setiap penyajian informasi di laporan keuangan semestinya mampu memiliki keterkaitan sesuai tujuan penyusunan laporan keuangan yang pada akhirnya informasi tersebut menghasilkan nilai prediksi dan nilai masukan, serta waktunya memiliki ketepatan.

3. Keandalan

Laporan keuangan mampu memiliki keandalan bagi para pemakai laporan keuangan tersebut. Penyusunan laporan keuangan tersaji akurat, sesuai kebenarannya, nyata, tidak diperlukan adanya rekayasa sedemikian rupa dimaksudkan agar tujuan khusus agar memuaskan beberapa pihak tertentu yang pada akhirnya informasi tersebut sewajarnya netral, dan tersaji kejujurannya, serta bisa diverifikasi.

4. Dapat dibandingkan

Laporan keuangan tersaji dengan metode yang serupa bagi perusahaan yang berbeda dan penggunanya mampu memiliki daya banding laporan keuangan dalam memperhatikan trend berikut kinerja keuangannya. Penyusunan laporan keuangan untuk itu harus konsisten pelaksanaannya dengan kebijakan serupa supaya bisa memiliki daya dalam hal antar entitas berikut pula dari perbedaan antar periode. 


\section{Kerangka Pemikiran}

Hanushek et al., (2017) Hampir semua negara, dalam upaya mereka untuk mendorong pembangunan ekonomi, memperkenalkan kebijakan untuk meningkatkan keterampilan kaum muda mereka (angkatan kerja masa depan), untuk menarik orang-orang terampil dari negara bagian atau negara lain, dan sebaliknya meningkatkan modal pengetahuan angkatan kerja mereka. Seorang yang memiliki jiwa wirausaha selayaknya memahami pencatatan transaksi keuangan berikut pelaporan akuntansi sebab dalam aktivitas bisnis itu tidak semata-mata melaksanakan aktivitas dalam periode satu bulan saja dan begitu satu atau dua tahun saja namun beberapa tahun, sehingga mustahil perusahaan dapat mengingat keseluruhan kejadian transaksi pada tiap aktivitas sebuah bisnis mengabaikan proses berikut keteraturan sistem pencatatannya dan sistematis, sehingga pengetahuan akuntansi diperlukan agar pembuatan suatu informasi akuntansi pada bisnis tertentu Hendro (2011). Penelitian sebelumnya yang pernah dilakukan oleh Baihaqi (2017) dan Purwati (2014), menemukan bahwa ada pengaruhnya pengetahuan akuntansi pada kualitas laporan keuangan. Penerapan kualitas sistem informasi akuntansi yang baik akan menghasilkan kualitas informasi akuntansi yang baik juga digunakan oleh pengguna dalam membuat keputusan Purnamasari (2016). Penelitian terdahulu oleh Agustin (2019) dan Rivaldi (2019) juga menemukan bahwa kualitas sistem informasi akuntansi dan komitmen organisasi mempengaruhi kualitas laporan keuangan.

\section{METODE PENELITIAN}

Penulis dalam melakukan penelitian adalah metode deskriptif kuantitatif dengan mendeskripsikan terkait pengaruh Pengetahuan Akuntansi dan Kualitas Sistem Informasi Akuntansi terhadap Kualitas Laporan Keuangan. Objek penelitian dalam penelitian ini adalah Pengetahuan Akuntansi, Kualitas Sistem Informasi Akuntansi, dan Kualitas Laporan Keuangan. Untuk mengumpulkan data yang diperlukan dalam penelitian ini melalui pengamatan (observasi), wawancara (interview), kuesioner (kuesioner), dokumentasi dan pengalaman individu. Penelitian ini mengumpulkan data secara primer dengan menyebarkan kuesioner. Skala yang digunakan dalam penelitian ini adalah rating Likert dengan tingkatan pengukuran 5 titik. Yaitu titik 1 sampai 5 yang mengukur setiap item pernyataan di kuesioner. Dalam menjawab skala likert ini, responden hanya memberi tanda, misalnya checklist atau tanda silang pada jawaban yang dipilih sesuai pernyataan. Kuesioner yang telah diisi responden perlu dilakukan penyekoran. Berikut ini bobot penilaian pada skala Likert.

Tabel 1. Scoring Untuk Jawaban Kuesioner

\begin{tabular}{cc}
\hline Jawaban Kuesioner Pernyataan & Skor \\
\hline Sangat Setuju & 5 \\
Setuju & 4 \\
Kurang Setuju & 3 \\
Tidak Setuju & 2 \\
Sangat Tidak Setuju & 1 \\
\hline
\end{tabular}

Sumber : Noor, Juliansyah (2017)

Analisis Deskriptif digunakan untuk menggambarkan karakteristik variabel yang diteliti yang bertujuan untuk mendukung pemecahan masalah dan memperoleh saran secara operasional. Analisis deskriptif kuantitatif menggambarkan bagaimana masing-masing variabel penelitian yang dilakukan di UMKM Alas Kaki Cimahi untuk selanjutnya diolah menjadi data. 


\section{HASIL PENELITIAN DAN PEMBAHASAN}

\section{Hasil penelitian}

\section{Hasil Tanggapan Responden mengenai Pengetahuan Akuntansi}

Pengetahuan akuntansi di UMKM Alas Kaki Cimahi akan terungkap melalui jawaban responden terhadap pernyataan-pernyataan yang diajukan pada kuesioner. Pada pengetahuan akuntansi dari enam butir pernyataan yang terdiri dari indikator identifikasi, pencatatan, dan komunikasi. Untuk mengetahui gambaran secara menyeluruh tentang pengetahuan akuntansi maka dilakukan perhitungan persentase skor jawaban responden pada setiap butir pernyataan. Berdasarkan perhitungan persentase skor jawaban responden diperoleh hasil seperti tampak depan tabel berikut :

Tabel 2. Rekapitulasi Tanggapan Responden Mengenai Pengetahuan Akuntansi

\begin{tabular}{cccccc}
\hline No. & Indikator & $\begin{array}{c}\text { Skor } \\
\text { Aktual }\end{array}$ & $\begin{array}{c}\text { Skor } \\
\text { Ideal }\end{array}$ & Presentase & Kriteria \\
\hline 1 & Identifikasi & 46 & 70 & $65,71 \%$ & Cukup \\
2 & Pencatatan & 43 & 70 & $61,43 \%$ & Cukup \\
3 & Komunikasi & 32 & 70 & $45,71 \%$ & Kurang \\
& Total & 121 & 210 & $57,62 \%$ & Cukup \\
\hline
\end{tabular}

Sumber : Data diolah (2020)

Berdasarkan tabel tersebut variabel pengetahuan akuntansi memperoleh skor sebesar 121 atau $57,62 \%$ berada pada kriteria cukup terletak pada interval 52-68\%. Berdasarkan rekapitulasi hasil tanggapan responden seperti pada tabel, diketahui bahwa indikator identifikasi memiliki skor paling besar yaitu $65,71 \%$ dan indikator komunikasi memiliki skor paling rendah yaitu 45,71\%. Ini berarti bahwa pengetahuan akuntansi pada UMKM Alas Kaki Cimahi sudah cukup. Pengetahuan akuntansi ini terdiri dari 3 indikator yaitu identifikasi, pencatatan, dan komunikasi. Indikator identifikasi memiliki skor $46(65,71 \%)$ berada pada rentang skor cukup (52-68\%), hal ini berarti responden cukup dalam memahami pengidentifikasian beberapa bukti transaksi sesuai jenis transaksinya supaya bisa dilaksanakan penjurnalan. Indikator pencatatan memiliki skor 43 $(61,43 \%)$ berada pada rentang skor cukup (52-68\%), hal ini berarti responden cukup memahami pencatatan beberapa transaksi sesuai kronologis berikut sistematikanya serta telah teridentifikasi berbentuk pencatatan perusahaan misalnya jurnal diikuti buku besarnya, kemudian neraca saldo, selanjutnya buku pembantunya serta buku harian lainnya. Indikator komunikasi memiliki skor 32 $(45,71 \%)$ berada pada rentang skor kurang baik (36-52\%), hal ini berarti responden kurang baik dalam memahami proses mengkomunikasikan situasi keuangan berikut menyusunan laporan keuangan disamping disajikannya untuk para pengguna laporan keuangan supaya mendukung keputusan yang diambilnya.

\section{Hasil Tanggapan Responden mengenai Kualitas Sistem Informasi Akuntansi}

Kualitas sistem informasi akuntansi di UMKM Alas Kaki Cimahi akan terungkap melalui jawaban responden terhadap pernyataan-pernyataan yang diajukan pada kuesioner. Pada kualitas sistem informasi akuntansi dari enam butir pernyataan yang terdiri dari indikator fleksibel, efektif dan efisien. Untuk mengetahui gambaran secara menyeluruh tentang kualitas sistem informasi akuntansi maka dilakukan perhitungan persentase skor jawaban responden pada setiap butir pernyataan. Berdasarkan perhitungan persentase skor jawaban responden diperoleh hasil seperti tampak dibawah berikut : 
Tabel 3. Rekapitulasi Tanggapan Responden Mengenai Kualitas Sistem Informasi Akuntansi

\begin{tabular}{cccccc}
\hline No. & Indikator & $\begin{array}{c}\text { Skor } \\
\text { Aktual }\end{array}$ & $\begin{array}{c}\text { Skor } \\
\text { Ideal }\end{array}$ & Presentase & Kriteria \\
\hline 1 & Fleksibel & 48 & 70 & $68,57 \%$ & Baik \\
2 & Efektif & 44 & 70 & $62,86 \%$ & Cukup \\
3 & Efisien & 34 & 70 & $48,57 \%$ & Kurang \\
& Total & 126 & 210 & $60,00 \%$ & Cukup \\
\hline
\end{tabular}

Sumber : Data diolah (2020)

Berdasarkan tabel tersebut variabel kualitas sistem informasi akuntansi memperoleh skor sebesar 126 atau 60,00\% berada pada kriteria cukup baik terletak pada interval 52-68\%. Berdasarkan rekapitulasi hasil tanggapan responden seperti pada tabel, diketahui bahwa indikator fleksibel memiliki skor paling besar yaitu $68,57 \%$ dan indikator efisien memiliki skor paling kecil yaitu $48,57 \%$. Ini berarti bahwa kualitas sistem informasi akuntansi sudah cukup baik. Kualitas sistem informasi akuntansi ini terdiri dari 3 indikator yaitu fleksibel, efektif, dan efisien. Indikator fleksibel memiliki skor $48(68,57 \%)$ berada pada rentang skor baik $(68-84 \%)$, hal ini berarti responden setuju bahwa sistem informasi akuntansi pada tempat usahanya dapat dengan mudah dan cepat menyesuaikan pada perubahan lingkungan begitu pula bisa sesuai kebutuhan perusahaannya dalam menampilkan kembali data-data yang diperlukan dan menampilkannya dalam format yang berbeda. Indikator efektif memiliki skor $44(62,86 \%)$ berada pada rentang skor cukup baik (52-68\%), hal ini berarti responden setuju bahwa sistem informasi akuntansi pada tempat usahanya cukup mampu menghasilkan output yang lengkap dan sesuai dengan kebutuhan pengguna informasi baik internal maupun eksternal dalam mendukung proses bisnis dan tugas untuk pengambilan keputusan, serta disajikan dalam waktu dan format yang tepat, konsisten dengan format sebelumnya sehingga mudah dimengerti. Indikator efisien memiliki skor 34 $(48,57 \%)$ berada pada rentang skor kurang baik (36-52\%), hal ini berarti responden menyatakan bahwa sistem informasi akuntansi pada tempat usahanya kurang baik dalam pemrosesan kecepatan informasi dan ketepatannya meminimalisir adanya pemborosan dan kerugian pada sumber daya.

\section{Hasil Tanggapan Responden mengenai Kualitas Laporan Keuangan}

Kualitas laporan keuangan di UMKM Alas Kaki Cimahi akan terungkap melalui jawaban responden terhadap pernyataan-pernyataan yang diajukan pada kuesioner. Pada kualitas laporan keuangan dari delapan butir pernyataan yang terdiri dari indikator dapat dipahami, relevan, keandalan dan dapat dibandingkan. Untuk mengetahui gambaran empirik secara menyeluruh tentang kualitas laporan keuangan maka dilakukan perhitungan persentase skor jawaban responden pada setiap butir pernyataan. Berdasarkan perhitungan persentase skor jawaban responden diperoleh hasil seperti tampak dibawah.

Tabel 4. Rekapitulasi Tanggapan Responden Mengenai Kualitas Laporan Keuangan (Y)

\begin{tabular}{cccccc}
\hline No. & Indikator & Skor Aktual & Skor Ideal & Presentase & Kriteria \\
\hline 1 & Dapat Dipahami & 36 & 70 & $51,43 \%$ & Kurang \\
2 & Relevan & 40 & 70 & $57,14 \%$ & Cukup \\
3 & Keandalan & 24 & 35 & $68,57 \%$ & Baik \\
\hline
\end{tabular}




\section{JURNAL AKUNTANSI, Vol. 10, No. 2, November (2021)}

\begin{tabular}{cccccc}
\hline No. & Indikator & Skor Aktual & Skor Ideal & Presentase & Kriteria \\
\hline 4 & $\begin{array}{c}\text { Dapat } \\
\text { Dibandingkan } \\
\text { Total }\end{array}$ & 45 & 70 & $64,29 \%$ & Cukup \\
\hline
\end{tabular}

Sumber : Data diolah (2020)

Berdasarkan tabel tersebut variabel kualitas laporan keuangan memperoleh skor sebesar 145 atau 59,18\% berada pada kriteria cukup baik terletak pada interval 52-68\%. Berdasarkan rekapitulasi hasil tanggapan responden seperti pada tabel, diketahui bahwa indikator keandalan memiliki skor paling besar yaitu 68,57\% dan indikator dapat dipahami memiliki skor paling kecil yaitu 51,43\%. Ini berarti bahwa kualitas laporan keuangan pada UMKM Alas Kaki Cimahi cukup baik. Kualitas laporan keuangan ini terdiri dari 4 indikator yaitu dapat dipahami, relevan, keandalan, dan dapat dibandingkan. Indikator dapat dipahami memiliki skor $36(51,43 \%)$ berada pada rentang skor kurang baik (36-52\%), hal ini berarti responden menyatakan bahwa laporan keuangan pada tempat usahanya belum dapat disusun dan disajikan secara sistematis sesuai dengan pemahaman pengguna laporan keuangan. Indikator relevan memiliki skor $40(57,14 \%)$ berada pada rentang skor cukup baik (52-68\%), hal ini berarti responden setuju bahwa laporan keuangan pada tempat usahanya sudah cukup baik disusun secara tepat bagi pengguna pada saat pengambilan keputusannya, hal ini menyebabkan setiap penyajian informasi di laporan keuangan semestinya mampu memiliki keterkaitan sesuai tujuan penyusunan laporan keuangan yang pada akhirnya informasi tersebut menghasilkan nilai prediksi dan nilai masukan, serta waktunya memiliki ketepatan. Indikator keandalan memiliki skor $24(68,57 \%)$ berada pada rentang skor baik (68-84\%), hal ini berarti responden setuju bahwa laporan keuangan pada tempat usahanya tersaji akurat, sesuai kebenarannya, nyata, tidak diperlukan adanya rekayasa sedemikian rupa dimaksudkan agar tujuan khusus agar memuaskan beberapa pihak tertentu yang pada akhirnya informasi tersebut sewajarnya netral, dan tersaji kejujurannya, serta bisa diverifikasi. Indikator dapat dibandingkan memiliki skor $45(64,29 \%)$ berada pada rentang skor baik $(68-84 \%)$, hal ini berarti responden setuju bahwa laporan keuangan pada tempat usahanya tersaji dengan metode yang serupa bagi perusahaan yang berbeda dan penggunanya mampu memiliki daya banding laporan keuangan dalam memperhatikan trend berikut kinerja keuangannya.

\section{PEMBAHASAN}

\section{Pengetahuan Akuntansi}

Tanggapan responden terhadap pernyataan mengenai pengetahuan akuntansi pada UMKM Alas Kaki Cimahi dapat dikatakan cukup baik, karena nilai persentase keseluruhan adalah sebesar 57,62\% yang mana berada pada rentang skor cukup (52-68\%). Artinya dengan pengetahuan akuntansi yang cukup, dapat mendukung terhadap kualitas laporan keuangan pada UMKM Alas Kaki Cimahi. Namun, terdapat gap sebesar 42,38\%, Kondisi tersebut memperlihatkan adanya kelemahan pada indikator pengetahuan akuntansi. Penelitian ini menjawab fenomena yang terjadi pada UMKM Alas Kaki Cimahi bahwa pemilik menata keuangan berbekal minim pengetahuan akuntansinya dan fokusnya lebih memperhatikan pendapatan lebih besar dari modal awal serta mengabaikan laporan keuangan sebagai dasar keputusan yang diambil dalam usahanya. Fenomena ini melanggar indikator pengetahuan akuntansi yaitu komunikasi, belum memahami keadaan keuangan dalam laporan keuangan sebagai pemakai laporan keuangan yang bermanfaat dalam menentukan keputusan yang diambilnya.. Hal ini sesuai dengan total skor tanggapan responden atas indikator komunikasi sebesar 45,71\% ini dikategorikan kurang baik dan masih terdapat gap sebesar 54,29\%, hal ini menunjukkan bahwa masih terdapat kelemahan dalam indikator komunikasi. Sesuai dengan 
pernyataan Chen, A., \& Gong, J. J. (2019) untuk mengatasi tantangan baru yang ditimbulkan oleh teknologi yang muncul ini, penting untuk melihat pendidikan akuntansi dari perspektif berorientasi klien yang menerapkan pendekatan pembelajaran yang mendalam dan mengambil pandangan strategis untuk lebih menyelaraskan pendidikan akuntansi dengan persyaratan pasar global. Menurut Grossi et al., (2019) dengan cara yang lebih induktif akan dimungkinkan dan pengetahuan kita tentang bagaimana proses akuntansi dan akuntabilitas dalam pengaturan empiris ini bekerja atau tidak bekerja akan meningkat.

\section{Kualitas Sistem Informasi Akuntansi}

Tanggapan responden terhadap pernyataan mengenai kualitas sistem informasi akuntansi pada UMKM Alas Kaki Cimahi dapat dikatakan cukup baik, karena nilai persentase keseluruhan adalah sebesar 60,00\% yang mana berada pada rentang skor cukup baik (52-68\%). Artinya dengan kualitas sistem informasi akuntansi yang baik, dapat mendukung terhadap kualitas laporan keuangan pada UMKM Alas Kaki Cimahi. Namun, terdapat gap sebesar 40,00\%, hal ini menunjukkan bahwa masih terdapat kelemahan pada indikator kualitas sistem informasi akuntansi. Penelitian ini menjawab fenomena yang terjadi pada UMKM Alas Kaki Cimahi bahwa belum bisa memaksimalkan peluang teknologi dalam mengembangkan usahanya dengan sistem yang belum terintegrasi sehingga kualitas laporan keuangan belum maksimal. Hal ini melanggar indikator kualitas sistem informasi akuntansi yaitu efisien, sistem belum dapat memproses informasi secara cepat dan tepat dengan meminimalisir pemborosan dan kerugian sumber daya. Hal ini sesuai dengan total skor terendah tanggapan responden atas indikator efisien sebesar 48,57\% ini dikategorikan kurang baik dan masih terdapat gap sebesar 51,43\%, hal ini menunjukkan bahwa masih terdapat kelemahan dalam indikator efisien. Untuk itu Rosa \& Purfini (2019) dan Lilis Puspitawati \& Sri Dewi Anggadini. (2011) mengatakan Sistem informasi akuntansi mampu memberikan kemudahan bagi akuntan. Sehingga baik perusahaan besar maupun perusahaan berkembang akan memiliki aplikasi akuntansi yang baik dengan kualitas yang baik. Azhar Susanto (2017) dan Sri Dewi Anggadini (2015) menyatakan kualitas sistem informasi akuntansi belum sepenuhnya baik, hal ini dikarenakan fleksibilitas sistem informasi akuntansi yang kurang memadai terlihat dari verifikasi yang dilakukan dimana sistem tersebut belum mudah untuk dipelajari, belum mudah digunakan namun belum kuat (sering terjadi kesalahan). Karena masih adanya permasalahan dalam sistem informasi akuntansi kepuasan (kecanggihan) juga menjadi bagian penting dalam implementasi sistem informasi terutama kepuasan dalam mengakses sistem dan integrasi data dari sistem.

\section{Kualitas Laporan Keuangan}

Tanggapan responden terhadap pernyataan mengenai kualitas laporan keuangan pada UMKM Alas Kaki Cimahi dapat dikatakan cukup baik, karena nilai persentase keseluruhan adalah sebesar 59,18\% yang mana berada pada rentang skor cukup baik (52-68\%). Artinya laporan keuangan yang dihasilkan pada UMKM Alas Kaki Cimahi sudah cukup baik didukung oleh pengetahuan akuntansi yang memiliki nilai persentase keseluruhan sebesar 57,62\% yang mana berada pada rentang skor cukup baik (52-68\%) dan kualitas sistem informasi akuntansi yang juga memiliki nilai persentase keseluruhan sebesar $60,00 \%$ yang mana berada pada rentang skor cukup baik (52-68\%). Namun, terdapat gap sebesar 42,38\%, hal ini menunjukkan bahwa masih terdapat kelemahan 40,00\% pada indikator kualitas laporan keuangan. Penelitian ini menjawab fenomena yang terjadi pada bahwa pelaku menjalankan usaha tanpa membuat laporan keuangan secara maksimal karena minimnya literasi keuangan mereka. Hal ini melanggar indikator kualitas laporan keuangan yaitu dapat dipahami, laporan keuangan belum disusun dan disajikan secara sistematis sesuai dengan pemahaman pengguna laporan keuangan. Hal ini sesuai dengan total skor terendah tanggapan responden atas indikator dapat dipahami sebesar 51,43\% ini dikategorikan kurang baik dan masih terdapat gap sebesar 48,57\%, hal ini menunjukkan bahwa masih terdapat kelemahan dalam indikator dapat dipahami. 


\section{PENUTUP}

\section{Simpulan}

Berdasarkan hasil analisis dan pembahasan pada bab sebelumnya, penelitian ini memiliki implikasi manajerial berupa penambahan pengetahuan mengenai informasi akuntansi berkualitas tidak terlepas dari faktor pengetahuan pengguna dan sistem informasi akuntansi yang diterapkan. Adapun kelemahan dari penelitian ini adalah jumlah sampel (responden) yang terbatas karena kondisi covid 19.

Tanggapan responden terhadap pernyataan mengenai pengetahuan akuntansi pada UMKM Alas Kaki Cimahi dapat dikatakan cukup baik. Artinya dengan pengetahuan akuntansi yang cukup, dapat berdampak pada kualitas laporan keuangan pada UMKM Alas Kaki Cimahi. Namun, masih terdapat kelemahan pada indikator pengetahuan akuntansi di UMKM Alas Kaki Cimahi yang menyebabkan pengetahuan akuntansi belum maksimal. Salah satunya yaitu pemilik menata keuangan berbekal minim pengetahuan akuntansinya dan fokusnya lebih memperhatikan pendapatan lebih besar dari modal awal serta mengabaikan laporan keuangan sebagai dasar keputusan yang diambil dalam usahanya, Hal tersebut memperlihatkan adanya kelemahan dalam indikator komunikasi pada pengetahuan akuntansi di UMKM Alas Kaki Cimahi.

Tanggapan responden terhadap pernyataan mengenai kualitas sistem informasi akuntansi pada UMKM Alas Kaki Cimahi dapat dikatakan cukup baik. Artinya dengan kualitas sistem informasi akuntansi yang baik, dapat berdampak pada kualitas laporan keuangan pada UMKM Alas Kaki Cimahi. Namun, masih terdapat kelemahan pada indikator kualitas sistem informasi akuntansi di UMKM Alas Kaki Cimahi yang menyebabkan kualitas sistem informasi akuntansi belum maksimal. Salah satunya yaitu bahwa belum bisa memaksimalkan peluang teknologi dalam mengembangkan usahanya dengan sistem yang belum terintegrasi sehingga kualitas laporan keuangan belum maksimal, kondisi tersebut memberi gambaran adanya kelemahan dalam indikator efisien pada kualitas sistem informasi akuntansi di UMKM Alas Kaki Cimahi.

Tanggapan responden terhadap pernyataan mengenai kualitas laporan keuangan pada UMKM Alas Kaki Cimahi dapat dikatakan cukup baik. Artinya laporan keuangan yang dihasilkan pada UMKM Alas Kaki Cimahi sudah cukup baik didukung oleh pengetahuan akuntansi dan kualitas sistem informasi akuntansi cukup baik pula. Namun, masih terdapat kelemahan pada indikator kualitas laporan keuangan di UMKM Alas Kaki Cimahi yang menyebabkan kualitas laporan keuangan belum maksimal. Salah satunya yaitu laporan keuangan belum disusun dan disajikan secara sistematis sesuai dengan pemahaman pengguna laporan keuangan, kondisi yang tidak jauh berbeda yang memperlihatkan adanya kelemahan dalam indikator dapat dipahami pada kualitas laporan keuangan di UMKM Alas Kaki Cimahi.

\section{Saran}

Hasil penelitian ini dapat digunakan sebagai referensi bagi peneliti lain sebagai tambahan referensi dalam melakukan penelitian. Bagi peneliti selanjutnya disarankan sebaiknya memperluas area survey pada lebih banyak lagi UMKM pengguna sistem informasi. Sehingga akan diperoleh sampel yang lebih banyak dan hasil yang lebih akurat, serta dapat melengkapi penelitian dengan metode analisis jalur atau yang lebih kompleks seperti SEM PLS. 


\section{REFERENSI}

Agustin, D. (2019). Pengaruh Kualitas Sistem Informasi Akuntansi Terhadap Kualitas Laporan Keuangan Pemerintah Daerah (Studi Kasus Pada Organisasi Perangkat Daerah Kota Bengkulu). Doctoral Dissertation, Universitas Muhammadiyah Palembang, 10-84.

Algrari, D. A. Y., \& Ahmed, M. R. M. (2019). The impact of Accounting Information Systems' Quality on Accounting Information Quality. Journal of Information Technology Management.

Azhar Susanto. (2017). The Effect of Internal Control on Accounting Information System. International Journal of Law and Management.

Baihaqi, W. (2017). Pengaruh Persepsi Pemilik atas Tujuan Laporan Keuangan dan Pengetahuan Akuntansi Pelaku Usaha terhadap Kualitas Laporan Keuangan pada Usaha Mikro Kecil Menengah (UMKM) (Studi Kasus pada UMKM di Kabupaten Banjarnegara. 4, 9-15.

Chen, A., \& Gong, J. J. (2019). Accounting comparability, financial reporting quality, and the pricing of accruals. Advances in Accounting, 45, 100415. https://doi.org/10.1016/j.adiac.2019.03.003

Cheung, E., Evans, E., \& Wright, S. (2010). An historical review of quality in financial reporting in Australia. Pacific Accounting Review, 22(2), 147-169. https://doi.org/10.1108/01140581011074520

Grossi, G., Kallio, K. M., Sargiacomo, M., \& Skoog, M. (2019). Accounting, performance management systems and accountability changes in knowledge-intensive public organizations: A literature review and research agenda. Accounting, Auditing and Accountability Journal, 33(1), 256-280. https://doi.org/10.1108/AAAJ-02-2019-3869

Hani, S., Mariati, \& Harahap, R. u. (2018). Laporan Keuangan UKM Syariah: Sebuah Model. In Lembaga Penelitian dan Penulisan Ilmiah Aqli.

Hanushek, E. A., Ruhose, J., \& Woessmann, L. (2017). Knowledge capital and aggregate income differences: Development accounting for US States. American Economic Journal: Macroeconomics, 9(4), 184-224. https://doi.org/10.1257/mac.20160255

Hendro. (2011). dasar dasar kewirausahaan. Erlangga.

Laudon, Kenneth.C and Laudon Jane P. (2014). Management Information System: Managing The Digital Firm. 10th Edition. Pearson Education Inc. Pearson Prentice Hall.

Lilis Puspitawati \& Sri Dewi Anggadini. (2011). Sistem Informasi Akuntansi. Yogyakarta: Graha Ilmu.

Meiryani, \& Susanto, A. (2018). The influence of information technology on the quality of accounting information system. ACM International Conference Proceeding Series, 109115. https://doi.org/10.1145/3234664.3234671

Muda, I. (2017). sistem informasi akuntansi. Penerbit Madenatera.

Noor, Juliansyah. (2017). Metodologi Penelitian: Skripsi, Tesis, Disertasi \& Karya Ilmiah. Jakarta: Prenada Media.

Purnamasari, R. (2016). Pengaruh Kualitas Sistem Informasi Akuntansi Terhadap Kualitas Informasi Akuntansi dan Implikasinya Pada Kepuasan Pengguna Akhir (Studi Kasus Pada PT. PLN (Persero) Distribusi Jawa Barat dan Banten). Jurnal Program Studi Akuntansi, Fakultas Ekonomi, Universitas Komputer Indonesia, Hal. 3:4:5.

Purwati, A. S. (2014). Faktor-Faktor Yang Mempengaruhi Kualitas Laporan Keuangan Pada UMKM Di Kabupaten Banyumas. Jurnal Banyumas. Artikel jp. feb. unsoed. ac. id 
Rivaldi, M. O. (2019). Pengaruh Kualitas Sistem Informasi Akuntansi Dan Komitmen Organisasi Terhadap Kualitas Laporan Keuangan Pemerintah Daerah (Studi Kasus Pada Kantor Pemerintah Kabupaten Bandung Barat).

Rosa, D., \& Purfini, A. P. (2019). Analysis Effect Quality of Accounting Information Systems to Support Company Performance. IOP Conference Series: Materials Science and Engineering, 662(3). https://doi.org/10.1088/1757-899X/662/3/032015

Sri Dewi Anggadini. (2015). Accounting Information System Quality Related to Ethics and Competence of User's. International Journal of Applied Business and Economic Research. 13(5):3143-3158.

Walujo, D. A., Koesdijati, T., \& Utomo, Y. (2018). pengendalian kualitas. Scopindo Media Pustaka.

Weygandt, J., Kimmel, P. D., \& Kieso, D. E. (2018). Accounting Principles (Thirteenth).

Zamzami, F., \& Nusa, N. D. (2016). Akuntansi Pengantar 1. ugm press. 